\title{
KNOWLEDGE MANAGEMENT CHALLENGES FOR START-UPS: A FRAMEWORK PROPOSAL
}

\author{
Theocharis Stylianos Spyropoulos \\ Department of International Business, Perrotis College \\ Email : info@exoha.biz, hspyro@afs.edu.gr
}

\begin{abstract}
Purpose: The study reviews the knowledge management challenges faced by innovative start-ups founders and entrepreneurs. Knowledge management is critical for innovation, since both organizations and individuals face very specific needs: collection of a wide variety of information and data, such as market data and technical information, and a wide range of transformation of these data into applicable knowledge, in the forms of required product specifications, business model, and business strategy. In addition, the business financing and investment ecosystem (especially Banks \& Venture Capitals) uses a traditional "business plan" approach for evaluating innovation companies. Furthermore, a wide range of tools (databases, online information, Collaboration Systems, Business Intelligence Systems, ERP \& CRM Systems) enable information flow and supports decision making process.
\end{abstract}

Design/methodology/approach: To this respect, both academic literature and business experience highlight the need to improve Knowledge Management process both for individuals and organizations engaged in Innovation management.

Findings: The proposed framework provides academics, entrepreneurs and venture capital companies a new approach for identifying critical success factors knowledge management and further improves decision making in a changing and challenging business environment. Finally the study highlights key areas for further research.

Research limitations/implications: This paper is a framework, so the result is in conceptual stage only.

Practical implications: This framework is able to adopted by researchers.

Originality/value: This paper if original.

Paper type: Conceptual paper

Keyword: Start Ups, Knowledge Management, Market Analysis, Product Mapping

Received: April $28^{\text {th }}, 2020$

Revised: September $4^{\text {th }}, 2020$

Published: September $30^{\text {th }}, 2020$

\section{INTRODUCTION}

The study reviews the key types of knowledge that are important to entrepreneurs and start-up companies. De Massis, Audretsch, Uhlaner, \& Kammerlander (2018) defines entrepreneurship as "the ability to identify, pursue and capture the value from business opportunities", while Blank (2013) defines startups as organisations formed to search for repeatable and scalable business models. "Knowledge management refers to identifying and leveraging the collective knowledge in an organisation to help the organisation compete." (Alavi \& Leidner, 2001). Trott (2017) also highlights the role of knowledge: "Technology is knowledge applied to products or production processes".

Further studies Bashir \& Farooq, (2019) examine the role of knowledge management on business model formation. They suggest that organisations should develop knowledge vision and mission and then relate 
knowledge to the business model, which creates a foundation for long term business success; organisations should invest in acquiring, interpreting and implement knowledge into business models. Furthermore, they conclude that knowledge converts into products and services that form the core of the business model. Further studies, Amit \& Zott (2012), Sosna, Trevinyo-Rodríguez, \& Velamuri, (2010) further discuss the role of Business Model innovation.

"A fundamental support of the performance of these organisations came, however, from an increased knowledge and better management information architecture within the organisation. (It should be said that the information architecture not only included hardware-based solutions but also better organisational processes to collect, analyze and disseminate knowledge)" (De Massis et al., 2018).

\section{A. Knowledge Challenges for New Companies}

Past academic studies define the range of knowledge required for new products and new business: "When a company selects and develops a product, it is determining its customers, competitors, suppliers, facilities, skill needs and the socioeconomic environment that will form the perimeter of its opportunity for success." (J. F. Christensen, 2002), while Hamel \& Prahalad (1994) highlight the impact of "changes in technology, lifestyles, regulation, demographics, and geopolitics".

There is a variety of models presenting the different phases of "'knowledge management", the way that knowledge is created and distributed within the company. 'The knowledge management level includes both individual and collective entities, the latter of which are further distinguished between groups (e.g. of relatively small collections such as work teams or functional departments) and organisations (e.g. relatively large collections such as enterprises or corporations). This dimension pertains to the scale of knowledge management and extends from a single person, through work groups, to an enterprise as a whole". (Nissen, Kamel, \& Sengupta, 2000). Furthermore "The structure of the organisation has important implications for the creation, retention, and dissemination of knowledge'". Nissen et al. (2000) and further research focusing on start-up companies Sekliuckiene, Vaitkiene, \& Vainauskiene (2018) links organisational level and number of employees with knowledge management needs and strategies.

Furthermore C. M. Christensen \& Overdorf (2000) examine disruptive solutions, and link development of disruptive solutions with product features and characteristics with a special appeal to market segments which are not, at the time of development, mainstream markets; therefore not a priority for established business. However, these market segments may grow rapidly, effectively changing the market. In addition, Baptista (2001) explores the way innovation is diffused within geographical, social and cultural clusters, providing a framework for market segmentation and targeting. Ries (2011) concludes that start-ups enable to test a number of hypotheses, mainly those related to value offered to customer and to growth potential. Further studies Chang, Chang, \& Li (2012), Feiz, Ghotbabadi, \& Khalifah (2016) focus on Customer Lifetime Value and on costs of customer acquisition (Ang \& Buttle, 2006). Livne, Simpson, \& Talmor (2011) also focus on the customer acquisition costs, while Min, Zhang, Kim, \& Srivastava (2016) highlights the value of customer retention in order to keep overall customer acquisition costs under control.

\section{B. The Role of Higher Education Systems}

Previous academic studies examine the role of Higher Education Systems. Minshall, Seldon, \& Probert (2007) examine the role of universities in providing start-ups with Intellectual Property in terms of knowledge through a wide variety of business models, such as spin-offs, consultancy by faculty members, IP Licensing, etc. Furthermore, Simoes, Silva, Trigo, \& Moreira (2012) highlight the role of higher education organisations as knowledge providers, who can provide ideas, resources and create spin-off start-up companies. Higher Education Institutes provide network opportunities, especially between parties that produce and can use knowledge. Gartner (1990) explores perceptions regarding entrepreneurship and innovation. Cho \& McLean (2009) also highlights the lack of closer ties with educational institutes for a high percentage of Asian start-ups.

In addition, Perren (2003) highlights the role of education and e-mentoring in entrepreneurship. Hayter (2013) suggests that university spin-offs that secure access to new technologies, knowledge, ideas, funding, and management are more likely to successfully launch their solutions. Colombo \& Piva (2008) highlighted the benefits of academics start-ups, mainly in terms of easiness to acquire capital and ecosystem benefits. Further study Spender, Corvello, Grimaldi, \& Rippa (2017) summarizes the findings of previous academic literature on the importance of higher education systems as knowledge providers. 
In addition, Roberts, Murray, \& Kim (2015) highlight the role of entrepreneurial education provided by Higher Education Organisations, and examines MIT's Entrepreneurial Education Impact. Aulet (2017) also concludes that "entrepreneurship can be taught". This conclusion is consistent with the findings of further academic research: Amit \& Zott (2012), Foss \& Saebi (2018), Gambardella \& McGahan (2010), Morgan, Vorhies, \& Mason (2009), Raj \& Srivastava (2016), Ries (2011), Evers (2003), they all highlight that entrepreneurial success starts with (or requires) a promising product; but business success starts with entrepreneurial education. It is therefore safe to conclude that the role and evolution of entrepreneurial education within the Higher Education System and third parties (e.g. Business Incubators and Accelerators) can be critical be future entrepreneurs.

\section{Start Ups Knowledge Challenges and Organisational Structures}

Academic studies provide a clear link between innovation, organisational structure and knowledge, highlighting the role of information and knowledge required for success. Chesbrough \& Teece (2002) distinguish autonomous (pursued independently from other organisations) and systemic (benefits realized only in conjunction with related innovations) innovation. "To understand why the two types of innovation call for different organisational strategies, consider the information flow essential to innovation. Information about new products and technologies often develops over time as managers absorb new research findings, the results of early product experiments, and initial customer feedback. To commercialize an innovation profitably, a tremendous amount of knowledge from industry players, from customers, and sometimes from scientists must be gathered and understood." (Chesbrough \& Teece, 2002).

"A product has two key dimensions. Technology - the fund of knowledge, technical and otherwise enabling the product to be economically produced and markets - to whom and how the product is to be sold enabling profitable distribution. These two characteristics are inseparable. An invention is not a new product until it is produced and distributed in a form that people can and will buy." (J. F. Christensen, 2002).

Linking product characteristics with market needs is always a critical challenge; marketers strive to identify which market segments appreciate more (or gain more value from) the special characteristics of their products. To this respect, Goyat (2011) discusses a variety of criteria for market segmentation while further academic studies introduce the concept of conjoined analysis, as a methodology for providing a better fit between product characteristics and market segments: "Conjoined analysis is a market segmentation methodology that "measures the various trade-offs that customers are willing to make when they buy a product (Grant, 1999).

Kam Sing Wong \& Tong (2012) highlight the importance of Product, Process and Management Technologies for the development of new products or creation of new businesses. Furthermore Hart \& Milstein (1999) provided a framework regarding Continuous Improvement and Creative Destruction of industries. According to their approach, industries can be either 'rationalized' by continuous improvements or being "creatively disrupted" by breakthrough innovation and technology. In both cases, there are significant knowledge requirements.

\section{METHODOLOGY}

\section{A. Start Ups: Learning Organisations on the path to Knowledge}

Past academic studies highlight a variety of knowledge challenges for start-ups. However in many cases the understanding of knowledge challenges is fragmented or focused on selective areas. "A venture starts with relatively imprecise and limited hypotheses about where an opportunity may lie. Multiple stages of information gathering and "pivoting" follow, as the business model is revised to arrive at the final, validated version. Typically, the founders radically change their hypotheses as the venture unfolds." (Girotra \& Netessine, 2014).

“The 'intangibles' that add value to most products and services are knowledge- based: technical knowhow, product design, marketing presentation, understanding the customer, personal creativity and innovation. Critical success factors for organisations today -the need for speed, management of complexity, a sense of history and context, effective judgment, and organisational flexibility- are all related to and dependent on organisational knowledge" (Herschel \& Nemati, 2000). Further studies conclude that "a learning effect dominates when firms are young and a vintage effect dominates when firms become mature... profitability is by far the chief reason for firm exit, since firms with negative profit are twice as likely to exit the industry.... 
firm performance, in terms of either profitability or productivity, becomes gradually more critical for firm survival over time (Bellone, Musso, Nesta, \& Quere, 2008).

Further studies conclude that: Ihrig \& MacMillan (2015) conclude"One thing we can assure you: Your competitors will have access to the same kinds of data and general industry knowledge that you do. So your future success depends on developing a new kind of expertise: the ability to leverage your proprietary knowledge strategically and to make useful connections between seemingly unrelated knowledge assets or tap fallow, undeveloped knowledge." Furthermore Ihring et al proposed a methodology for knowledge mapping, and for developing a strategy for knowledge management. In addition Denicolò \& Zanchettin (2010) link competition and innovation with strategic pricing. Rochford \& Wotruba (1996) explore the links between sales and new product success, highlighting the need to adjust the sales force when new products are launched; while Jones, Chonko, Rangarajan, \& Roberts (2007) highlight the recent changes to sales management.

Weaver (1995) summarizing Demming's views for innovation, provides two questions for a firm wishing to innovate: (a) which is our business scope? and (b) which will be the new products and/or services which will serve our customers needs better than the ones they have available and use today? In addition Weaver highlights Demming's Principals of Innovation, concluding the following:

Table 1. Demming's Principles of Innovation

$1 \quad$ In order to identify products or services that can help your customers improve their lives, study their processes. Collect and process information regarding customer's processes. Use this information to identify customer's problems, and offer solutions to them. Expand the definition of your business scope to include supplementary products and services to your existing product line. Study the environment that determines your customers processes Understand the way that environmental (technological, economical, social, political) changes will affect your customers processes, so that you can predict changes of these processes. Exploit the opportunity of these changes and your understanding of your customer's processes in order to develop new products and services that will serve your customers new processes.

3 Study the processes of your customer's customer

Your customers have to serve the needs of their own customers, in the industrial markets, or their own personal preferences in consumer products. By understanding the present and future needs of your customer's customer you will identify the future needs of your customer.

This intensive need for learning, from defining a set of knowledge scopes, to actual data and information collection, in a way to generate knowledge and apply this new knowledge to action immediately is the reason why management is the key determining factor for success. "In terms of the weight analysis of the determinants for start-up business, managerial ability was considered to be the most important factor in the USA, followed by marketing factors and economic/financial factors." (Lee \& Osteryoung, 2002). Evers (2003) summarizing previous academic literature, concludes that "Despite these attempts to offer an all encompassing framework, these variables are loosely defined, where more specific factors are needed." Evers (2003).

Ries (2011) identifies the fact that enables start-up companies to test fast the two riskier hypotheses of their business plan; the value (the actual value as perceived by the potential customer or user) and growth (ability of the start-up to grow fast enlisting new customers) assumptions. "The 'action-learning' process that characterizes many entrepreneurial corporations is a regular assessment of options, actions, and evaluation, combined with the active development and maintenance of knowledge... (De Massis et al., 2018). Stankevich (2017) summarizes consumer decisions processes. Solomon, Bamossy, Askegaard, \& Hogg (2006) define the decision-making process as the amount of effort that goes into the decision each time it must be made.

Further studies highlight the need for development of a minimum viable product: "For a start-up, it is essential to validate its value and growth hypotheses as soon as possible. In order to do that, the company has to come up with a version of its product that is complete enough to demonstrate the value it brings to the users: a minimum viable product (MVP). It then needs to design experiments that will use the MVP to confirm (or refute) its value and growth hypotheses.” (Rancic Moogk, 2012).

Brauer \& Schimmer (2010) emphasizes on the need of the company to identify and possess a strategic position in the market - or create one. According to Brauer \& Schimmer (2010) strategic positions are never permanent and new strategic positions always appear. Santisteban \& Mauricio (2017) summarizing previous 
research, conclude "According to Cho \& McLean (2009), Information Technology (IT) Startups, also referred to as new technology-based enterprises, are those temporary organisations that create innovative products and/or services using high technology, but this Type of companies are also known to be inserted in uncertain and risky scenarios, proof of this is their high mortality rate (Chang et al., 2012). In addition, LeRouge, Ma, Sneha, \& Tolle (2013) highlight the role of Persona Development for marketing purposes.

In addition, the way that innovations are introduced into the market leaves plenty of room available for legal consideration as far as compliance with existing legislation and ethics is concerned. Compliance, regulation and legal issues may create problems during the initial commercialization phase or several years later. The examples of Microsoft's Internet Explorer (which lead to trial for monopolistic behaviour, endangering the company structure, 1999), MP3.com and Napster.com (both in trial for permitting users violating copyright laws, 1999-2000), Uber (2017-2018), AirBnB (issues regarding income taxation, 20172018) and business ethics.

Brown (2017) introduce the concept of Scalable learning, concluding that it enables organisations regarding knowledge management; the more people they join, they learn faster, developing network externalities in knowledge management. This approach is of particular interest to high growing start-ups, with many employees on boarding.

According to Blank (2013) "lean start-up," strategy favours experimentation over elaborate planning, customer feedback over intuition, and iterative design over traditional "big design up front" development. Although the "lean start-up methodology" is just a few years old, its concepts - such as "minimum viable product" and "pivoting" - have quickly taken root in the start-up world, and business schools have already begun adapting their curricula to teach them (Blank, 2013).

With more hypotheses than actual knowledge, at least at the beginning and the first stages, start-ups are therefore organisations required to be able to collect data and information and transfer them to actual knowledge, in terms of product characteristics and market segments (and they need to do this fast); the startup therefore needs not only to be able to manage knowledge but to be a fast learning organisation. Actually start-uppers need to collect information and data, create knowledge (in terms of product requirements, specifications, market needs, people, and business or daily and transactional processes) and manage effectively this knowledge in order to develop a successful marker offering (product or service) to a new or existing market.

\section{B. Framework Discussion: 24 Steps to a Successful Start-Up}

Aulet (2017), published "Disciplined Entrepreneurship, 24 Steps to a Successful Start Up" which attempts to provide an integrated, analytical framework for the steps required in order to create a successful start-up company. Aulet highlights the role of entrepreneurial education and concludes that entrepreneurial education has to start before the product - has to do with identification of opportunities, or the creation of new markets. The value of Aulet's framework lays to the fact that it provides an integrated approach to practically all steps of entrepreneurial challenges and in fact includes Knowledge Challenges identified by previous academic studies. Aulet's approach provides an analytical guide to cover most challenges each startup has to come through, and, as such, it becomes easier to identify knowledge challenges in each step.

Salamzadeh \& Kawamorita (2015) distinguish three stages for start up development: Bootstrapping, Seed and Creation. Burns (2016), highlights the following key stages of Start-ups:

1. Discovering a business idea,

2. Evaluating the business idea

3. Developing a business model

4. Adding values to the business model (prices, costs, financial information)

5. Launching the business (team and human resources issues)

6. Legal Issues

7. Operations and Risk

8. Financial Management

Further studies Sekliuckiene et al. (2018), are based on the framework proposed by Salamzadeh \& Kawamorita (2015), however the authors develop a set of 11 sub-stages of start-up development; and their 
conclusions are highly linked to the size of the start-up and more specifically to the increasing number of employees.

Even though all the above frameworks highlight the stages of start-up evolution, and each stage can be used for linking certain development stages of the start-up with associated knowledge management challenges; however Aulet (2017) offers a more detailed analysis of the various stages of start-up development and for this reason the specific approach is used for linking development stages of start-up with knowledge management challenges.

Based on Aulet (2017) framework of Disciplined Entrepreneurship (24 steps), a number of knowledge challenges can be identified associated to each one of the 24 steps; to this respect, this approach provides a clear identification of Knowledge Challenges that each Start-Up needs to overcome. The following table (Table 2) presents the 24 Steps and the knowledge challenges associated with each step.

Table 2. 24 Steps (Aulet, 2017) and Knowledge Challenges

\begin{tabular}{|c|c|c|c|}
\hline $\begin{array}{l}\text { Step } \\
\text { No }\end{array}$ & Step & Knowledge Challenges & Related Academic References \\
\hline 0. & $\begin{array}{l}\text { Idea, } \\
\text { Passion or } \\
\text { Technology as drivers } \\
\text { that may resolve a } \\
\text { problem }\end{array}$ & $\begin{array}{l}\text { Start with an Idea, } \\
\text { Or a Passion to resolve a problem in a new way or approach } \\
\text { Or development of a new Technology which can be applied in } \\
\text { a new way that offers new alternative ways to resolve a } \\
\text { problem } \\
\text { Key Issues - Existing Knowledge (Education \& Career, } \\
\text { Abilities and Skills, Connections (Network), Financial Assets, } \\
\text { Name Recognition (Reputation), Past Work Experience, } \\
\text { Passion for a specific Market, Commitment) } \\
\text { Build your Founder's Team }\end{array}$ & $\begin{array}{l}\text { Chesbrough \& Teece (2002), } \\
\text { Cho \& McLean (2009), } \\
\text { Santisteban \& Mauricio (2017) }\end{array}$ \\
\hline 1. & Market Segmentation & $\begin{array}{l}\text { Identify Markets and Segments. } \\
\text { Define Criteria for Segmentation (Demographic, Usage, } \\
\text { Geographical, etc). } \\
\text { Define Relevant Segment Sizes } \\
\text { Segments not satisfied with existing solutions or business } \\
\text { models } \\
\text { Segments that can adopt fast a new product or product } \\
\text { approach and can fit into existing processes }\end{array}$ & $\begin{array}{l}\text { Market Segmentation is } \\
\text { discussed on Blank (2013), } \\
\text { Kam Sing Wong \& Tong } \\
(2012) \\
\text { Christensen (2002) } \\
\text { C. M. Christensen \& Overdorf } \\
\text { (2000) } \\
\text { Herschel \& Nemati (2000), }\end{array}$ \\
\hline 2. & $\begin{array}{l}\text { Select Beachhead } \\
\text { Market }\end{array}$ & $\begin{array}{l}\text { Evaluate Markets and Segments. } \\
\text { Willingness and Ability to Buy the new product } \\
\text { Purchasing Decisions \& Sales Cycles } \\
\text { Your ability to Access the segment } \\
\text { Size and Future Growth Potential } \\
\text { Competition }\end{array}$ & \\
\hline 3. & End User Profile & $\begin{array}{l}\text { Who will use the product? Why? } \\
\text { What are the goals, priorities and pains? How they match with } \\
\text { key product characteristics or business model? } \\
\text { How can the end user be approached? }\end{array}$ & LeRouge et al. (2013) \\
\hline 4. & $\begin{array}{l}\text { Total Addressable } \\
\text { Market (Beachhead) }\end{array}$ & $\begin{array}{l}\text { Number of Users \& Potential Customers. } \\
\text { How much money each customer will pay? } \\
\text { Future Growth? What are the demand factors? Market Size } \\
\text { Numbers and Trends. }\end{array}$ & Grant (1999) \\
\hline 5. & Persona (Beachhead) & $\begin{array}{l}\text { Job Title, Job Position, Key Tasks, Work Experience, Career } \\
\text { Interests and Ambitions, Key Skills, Family Status, Risk } \\
\text { taker/Innovator/early adopter }\end{array}$ & Similar to Step 4 \\
\hline 6. & Life Cycle Use Case & $\begin{array}{l}\text { How Product Fits to Customer/User daily processes? Scenarios } \\
- \text { How To - Best Practices. Customer ROI and key benefits } \\
\text { (saves time, money, reduce risk). Why Buy - Answers }\end{array}$ & Grant (1999) \\
\hline 7. & $\begin{array}{l}\text { High Level Product } \\
\text { Specification }\end{array}$ & $\begin{array}{l}\text { Product Characteristics, Features and User Benefits Lists. } \\
\text { Sizes, Versions, Leaflets. How Product Features fit into } \\
\text { customer needs - secure specific, (measurable if possible) } \\
\text { benefits. Product Mapping and Priorities. } \\
\text { Note: Product Specification has to consider conclusions from } \\
\text { the Segmentation \& Beachhead sections - product } \\
\text { characteristics and design is recommended to correspond to the } \\
\text { special requirement of the market segments and beachhead }\end{array}$ & $\begin{array}{l}\text { Kam Sing Wong \& Tong } \\
(2012)\end{array}$ \\
\hline
\end{tabular}




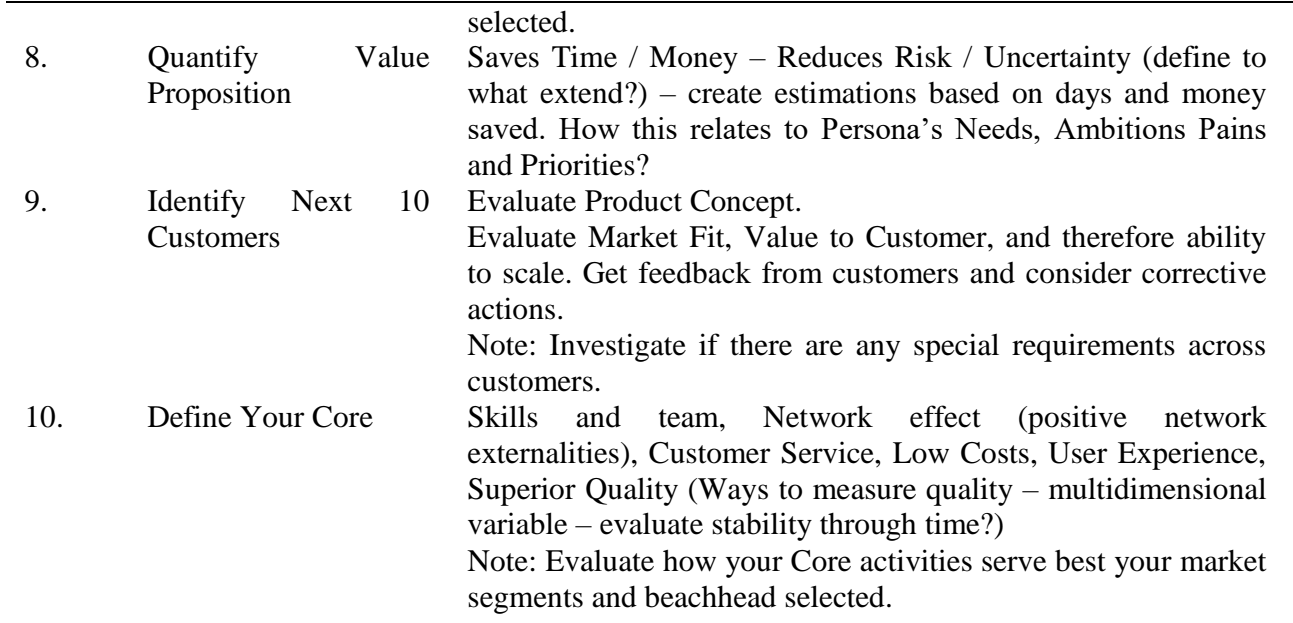

11. Chart Competitive Define the key criteria (2 to 6) for customer's purchasing Position

12. Customer Decision Making Unit
13. Map Process Paying Customer decisions in your segment / market. Define where you stand in relation to your competition, and how you can improve.

Note: Charting your competitive position may help entrepreneurs define their next moves and key areas where they need to focus more, and as a result, have an idea of the resources required to do so.

Who Participates? What are their roles (e.g. Product Champion, Influencers, Compliance, Finance/ROI)? How they Buy? Sales Cycle?

Note: Helps entrepreneurs develop selling propositions for each member of the customer decision making unit.

Buying Process, (e.g. tender or direct assignment?), Testing Period, Payment Terms, Warranties. Listing as Approved Supplier. Timeframe for each step.

Note: Helps entrepreneurs design their sales and marketing processes or even their business model, to shorten sales cycles. This step is closely associated with the cost of sales.

14. Total Addressable Evaluate markets / segments - define your next market / Markets Following segment after the beachhead. (Ideally 1 billion market value combined with beachhead for VCs). Selection Criteria and Market Analysis.

15. Musiness $\quad$ Model
Design

Define how the company Creates and Captures Value, in a sustainable way. Which type of business model is suitable for the segments and personas selected? The ideal business model creates a new set of market arrangements where existing competitors cannot follow fast enough. Analysis of Customer's Processes, Competition and Distribution Systems, Licensing and Pricing Models.

16. Pricing Framework Identify key Value and Price Points.

Examine Quantified Value Proposition.

Market Segments - sensitive or not to prices. Positioning Strategy. Business Model selected. Customer Cost of Ownership, Use and ROI.

17. Lifetime Value of One time or multiple payments or revenue streams. Customer Customer Retention Rates.

Product Life.

Cross Selling \& Further Business development opportunities (creation of additional income opportunities).

Business Model selected.

Targeted Segments.

Competition.

18. Map Sales Process
Sales Process Analysis.

From Lead Generation (Marketing)to close sales.

Sales Success Rates.

Organisational Changes of customers (managers - decision makers turnover)

Environmental - Compliance Changes
Ries, (2011)

Scalability issues discussed on Milat, King, Bauman, \& Redman (2013), Westley, Antadze, Riddell, Robinson, \& Geobey (2014), Øvretveit, Garofalo, \& Mittman (2017)

Ihrig \& MacMillan (2015)

Brauer \& Schimmer (2010)

Solomon et al. (2006)

Stankevich (2017)

Richardson (2016)

Brauer \& Schimmer (2010)

Bashir \& Farooq (2019), Sosna et al. (2010), Amit \& Zott (2012), Baden-Fuller \& Morgan (2010)

Denicolò \& Zanchettin (2010)

Chang et al. (2012),

Feiz et al. (2016)

Rochford \& Wotruba (1996)

Jones et al. (2007) 


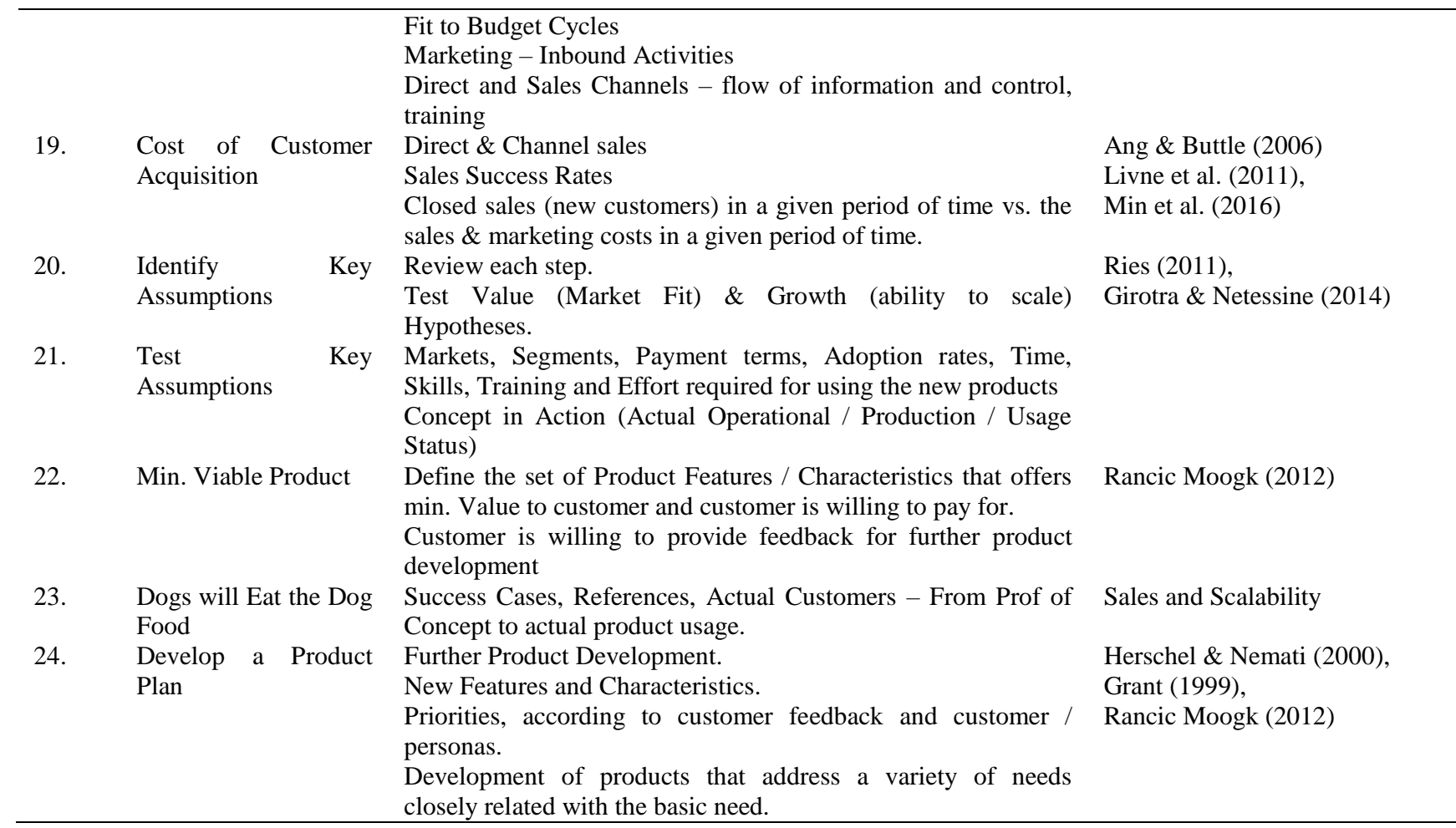

The table above provides a link between the steps necessary to build a successful start-up company and the knowledge challenges in each step of the way. Therefore, the specific approach creates an event-paced approach to knowledge required for a start-up company; once the goals of each step are accomplished, which requires relevant knowledge to be created and applied, the start-up can move to the next step, in order to face new knowledge challenges - again new knowledge has to created and applied successfully to let the start-up move to the next step.

This approach follows the lean start-up approach; not all knowledge is required in the first steps of the start-up formation, not even the official registration of a company. In fact, during the first steps the team has to be created and skills and experiences to be combined, and the first steps require a deep analysis of the market and the various segments that the start-up company wishes to serve (Steps 1-5). Steps 6, 7 and 8 are related to product characteristics, to the way the product fits into user processes and an evaluation of the value the product offers to end users.

The next steps have their own goals - identify customers, define (and protect) company's core, understand the processes that lead to paying customers before selecting a suitable business model and a pricing policy; then test hypotheses and explore further opportunities to grow.

\section{Knowledge Management \& Challenges}

Aulet's framework provides a set of knowledge challenges that are related to the start-up success. However once the start-up company is successful - at least at its first steps - new challenges appear; this time challenges are related with the task of managing the company.

To a certain degree, this type of knowledge management can have to do with management duties or supportive actions, which can be assigned to third parties (such as accounting and legal issues). However on the way that the successful start-up evolves into a company, a number of managerial related challenges arise in several functional areas. These involve Legal (company set up), Accounting, and aspects of management functions (Hiring and Training new employees, setting goals and budgets in each department, etc).

\section{CONCLUSION}

The study provides an integrated approach regarding the key Knowledge Challenges for start-up companies. 
First of all, three different types of Knowledge Challenges can be identified (table 3).

Table 3. Types of Knowledge Challenges

\begin{tabular}{|c|c|c|}
\hline $\begin{array}{l}\text { Type } \\
\text { No }\end{array}$ & Type & Knowledge Challenge Characteristics \\
\hline 1. & $\begin{array}{l}\text { General and } \\
\text { Specific Knowledge } \\
\text { Background (before } \\
\text { attempting to } \\
\text { establish a start-up) }\end{array}$ & $\begin{array}{l}\text { Knowledge available at the beginning; Entrepreneurial Education, Education \& Career, Abilities and } \\
\text { Skills, Connections (Network), Financial Assets, Name Recognition (Reputation), Past Work } \\
\text { Experience, Passion for a specific Market, Commitment) } \\
\text { Skills and abilities to establish founding teams and evaluate markets } \\
\text { (Responds to Aulet's Step 0) }\end{array}$ \\
\hline 2. & Start-Up Phase & $\begin{array}{l}\text { Specific Venture Knowledge } \\
\text { Hypotheses regarding the specific Start-Up venture and ability to develop processes to obtain and } \\
\text { apply specific venture knowledge that verifies or rejects hypotheses, and be able to take corrective } \\
\text { action whenever necessary (Responds to Aulet's Steps 1-24). Focused on Efficiency and Prof of } \\
\text { Concept/Feasibility of the Start-Up Venture. }\end{array}$ \\
\hline 3. & $\begin{array}{l}\text { Established } \\
\text { Company }\end{array}$ & $\begin{array}{l}\text { Knowledge Challenges related to Management of the company, and actions to secure further growth } \\
\text { and business expansion, product and market development. Focused on Performance and Operational } \\
\text { Effectiveness. }\end{array}$ \\
\hline
\end{tabular}

As a direct consequence, knowledge background (Level 1) can play a significant role, especially in the case of specific knowledge and entrepreneurial education, which enables would-be entrepreneurs to identify areas of possible business opportunities. However ability to create hypotheses, collect data, create and apply new knowledge, and take corrective action whenever necessary, is critical for a specific start-up venture (Level 2). Finally, managerial and growth-aimed knowledge (Level 3) is required once the start-ups become a success, in order to further manage the company.

The different knowledge challenges also require different ways to create the required knowledge; market research and data collection (including secondary data) may provide some useful hints, but in the end the market will respond - positive or not - to the value proposition (product or service proposal, Minimum Viable Product proposal), and actual customers and users may offer advice for further product development.

Furthermore, a key question depends on the vision of start-up founders; are they addressing current needs or aim for the future; data collection from mainstream customers may lead to development of product that fit current needs; or cost opportunities for disruptive approaches that may become leaders in the future. "Innovate incrementally on proven technology through a continued R\&D process". This way the firm develops modifications for the basic product and process "without undertaking major basic research in areas unrelated to the original successful innovation" (Grosse \& Kujawa, 1995). In addition, the ways Consumers and Buyers learn can also become a segmentation criterion in the future. Academic studies Shukla, Swami, \& Sharma (2010) distinguish process oriented learners, who focus on product features and ways to use the product, from content learners who focus on the end benefits.

Brauer \& Schimmer (2010) uses the example of fax market; while market research focused to current customer needs and willingness to buy prevented USA companies to commercialize fax technology which their customers responded they will not need, while Japanese companies, focused on the benefits that fax technology will be offering to their business customers, dominated this market for decades.

To this respect, market analysis and segmentation is of profound importance; and academic research provides a number of criteria and approaches for market segmentation. "Market segmentation is the art and science of partitioning people or things into distinct groups" (Grant, 1999). In addition, Conjoint Analysis provides a link between product characteristics and market segments; "the central idea of conjoint analysis is that products and services can be described by a set of attribute levels. Purchasers attach different values to the levels of different attributes. Then they choose the offering that has the highest total value, adding up all the part-worths" (Grant, 1999). Conjoint Analysis, along with market segmentation and design thinking methodologies enable start-ups to evaluate carefully their Minimum Viable Product approach, total value proposition and quantify the end user benefits.

Further academic research focused on disruptive innovation highlights a different potential approach. C. M. Christensen \& Overdorf (2000) conclude that as established companies focus on mainstream markets and invest in proved technologies to secure their market share in existing markets, they fail to realize and invest 
on new, disruptive technologies, which initially address to minor market segments. "The future is to be found in the intersection of changes in technology, lifestyles, regulation, demographics, and geopolitics....Seeing the future first requires not only a wide-angle lens, it requires a multiplicity of lenses. Thus, any group charged with finding the future needs to encompass an eclectic mix of individual perspectives"' (Hamel \& Prahalad, 1994).

Finally for companies that aim at customer service, Richardson (2016) highlights the role of customer journeys: "Mapping out all the steps a customer takes while interacting with your company is a powerful way to improve the experience. Customer journey maps clarify what customers are trying to do, what barriers they face, and how they feel during each interaction with your product or service. Refining these smaller steps, such as how people complete a purchase online or file a complaint, is what journey maps are known for." (Richardson, 2016).

\section{A. Limitations \& Areas for Future Research}

The study attempts to provide an understanding of the knowledge challenges faced by start-up companies; how they evolve from hypotheses statement, to hypotheses testing, in order to collect and process data and information to build the knowledge required; and their actual ability to apply their new knowledge into products and processes addressing specific segments and markets.

The study is based largely on Aulet's framework in order to identify key Knowledge Challenges for Start-Up companies. The reason for this is that Aulet's framework is a detailed guide that covers most challenges for establishing a successful start-up company. To this respect, development of new frameworks for establishing a successful Start-Up may reveal additional knowledge challenges in the future.

\section{REFERENCES}

Alavi, M., \& Leidner, D. E. (2001). Review: Knowledge Management and Knowledge Management Systems: Conceptual Foundations and Research Issues. MIS Quarterly, 25(1), 107. https://doi.org/10.2307/3250961

Amit, R., \& Zott, C. (2012). Creating Value Through Business Model Innovation, MIT Sloan Management Review. MIT Sloan, 53(3), 40-50.

Ang, L., \& Buttle, F. (2006). Managing For Successful Customer Acquisition: An Exploration. Journal of Marketing Management, 22(3-4), 295-317. https://doi.org/10.1362/026725706776861217

Aulet, B. (2017). 24 Steps to a Successful Start Up. In Disciplined Entrepreneurship Workbook. New Jersey: Wiley.

Baden-Fuller, C., \& Morgan, M. S. (2010). Business Models as Models. Long Range Planning, 43(2-3), 156-171. https://doi.org/10.1016/j.lrp.2010.02.005

Baptista, R. (2001). Geographical Clusters and Innovation Diffusion. Technological Forecasting and Social Change, 66(1), 31-46. https://doi.org/10.1016/S0040-1625(99)00057-8

Bashir, M., \& Farooq, R. (2019). The synergetic effect of knowledge management and business model innovation on firm competence. International Journal of Innovation Science, 11(3), 362-387. https://doi.org/10.1108/IJIS-10-2018-0103

Bellone, F., Musso, P., Nesta, L., \& Quere, M. (2008). Market selection along the firm life cycle. Industrial and Corporate Change, 17(4), 753-777. https://doi.org/10.1093/icc/dtn025

Blank, S. (2013). Why the Lean Start-Up Changes Everything. Retrieved from Harvard Business Review website: https://hbr.org/2013/05/why-the-lean-start-up-changes-everything

Brauer, M., \& Schimmer, M. (2010). Performance effects of corporate divestiture programs. Journal of Strategy and Management, 3(2), 84-109. https://doi.org/10.1108/17554251011041760

Burns, P. (2016). Entrepreneurship and Small Business: Start-up, Growth and Maturity (4th ed.). Palgrave Publication.

Chang, W., Chang, C., \& Li, Q. (2012). Customer Lifetime Value: A Review. Social Behavior and Personality: An International Journal, 40(7), 1057-1064. https://doi.org/10.2224/sbp.2012.40.7.1057

Chesbrough, H., \& Teece, D. J. (2002). When Is Virtual Virtuous? Retrieved from Harvard Business Review website: https://hbr.org/2002/08/when-is-virtual-virtuous

Cho, Y., \& McLean, G. N. (2009). Successful IT start-ups' HRD practices: four cases in South Korea. Journal of European Industrial Training, 33(2), 125-141. https://doi.org/10.1108/03090590910939030

Christensen, C. M., \& Overdorf, M. (2000). Meeting the Challenge of Disruptive Change. Retrieved from Harvard Business Review website: https://hbr.org/2000/03/meeting-the-challenge-of-disruptive-change 
Christensen, J. F. (2002). Corporate strategy and the management of innovation and technology. Industrial and Corporate Change, 11(2), 263-288. https://doi.org/10.1093/icc/11.2.263

Colombo, M. G., \& Piva, E. (2008). Strengths and Weaknesses of Academic Startups: A Conceptual Model. IEEE Transactions on Engineering Management, $37-49$. https://doi.org/10.1109/TEM.2007.912807

De Massis, A., Audretsch, D., Uhlaner, L., \& Kammerlander, N. (2018). Innovation with Limited Resources: Management Lessons from the German Mittelstand. Journal of Product Innovation Management, 35(1), 125-146. https://doi.org/10.1111/jpim.12373

Denicolò, V., \& Zanchettin, P. (2010). Competition, Market Selection and Growth. The Economic Journal, 120(545), 761-785. https://doi.org/10.1111/j.1468-0297.2009.02313.x

Evers, N. (2003). The Process and Problems of Business Start-Ups. The ITB Journal, 4(1).

Feiz, S., Ghotbabadi, A. R., \& Khalifah, Z. B. (2016). Customer Lifetime Value in Organizations. Asian Journal of Research in Social Sciences and Humanities, 6(5), 53. https://doi.org/10.5958/22497315.2016.00103.9

Foss, N. J., \& Saebi, T. (2018). Business models and business model innovation: Between wicked and paradigmatic problems. Long Range Planning, 51(1), 9-21. https://doi.org/10.1016/j.lrp.2017.07.006

Gambardella, A., \& McGahan, A. M. (2010). Business-Model Innovation: General Purpose Technologies and their Implications for Industry Structure. Long Range Planning, 43(2-3), 262-271. https://doi.org/10.1016/j.lrp.2009.07.009

Gartner, W. B. (1990). What are we talking about when we talk about entrepreneurship? Journal of Business Venturing, 5(1), 15-28. https://doi.org/10.1016/0883-9026(90)90023-M

Girotra, K., \& Netessine, S. (2014). Four Paths to Business Model Innovation. Retrieved from Harvard Business Review website: https://hbr.org/2014/07/four-paths-to-business-model-innovation

Goyat, S. (2011). The Basis Of Market Segmentation: A Critical Review Of Literature. European Journal of Business and Management, 3(9), 45-56.

Grant, R. (1999). The Resource-Based Theory of Competitive Advantage: Implications for Strategy Formulation. In Knowledge and Strategy (pp. 3-23). https://doi.org/10.1016/B978-0-7506-70883.50004-8

Grosse, R., \& Kujawa, D. (1995). International Business: Theory and Managerial Applications (3rd ed.). San Diego: Richard d Irwin.

Hamel, G., \& Prahalad, C. K. (1994). Competing for the Future. Retrieved from Harvard Business Review website: https://hbr.org/1994/07/competing-for-the-future

Hart, S. L., \& Milstein, M. B. (1999). Global Sustainability and the Creative Destruction of Industries.

Hayter, C. S. (2013). Harnessing University Entrepreneurship for Economic Growth. Economic Development Quarterly, 27(1), 18-28. https://doi.org/10.1177/0891242412471845

Herschel, R. T., \& Nemati, H. R. (2000). Chief Knowledge Officer: Critical Success Factors for Knowledge Management. Information Strategy: The Executive's Journal, 16(4), 37-45. https://doi.org/10.1080/07438613.2000.10744623

Ihrig, M., \& MacMillan, L. (2015). Managing Your Mission-Critical Knowledge. Retrieved from Harvard Business Review website: https://hbr.org/2015/01/managing-your-mission-critical-knowledge

III, J. H., \& Brown, J. S. (2017). Great Businesses Scale Their Learning, Not Just Their Operations. Retrieved from Harvard Business Review website: https://hbr.org/2017/06/great-businesses-scale-theirlearning-not-just-their-operations

Jones, E., Chonko, L., Rangarajan, D., \& Roberts, J. (2007). The role of overload on job attitudes, turnover intentions, and salesperson performance. Journal of Business Research, 60(7), 663-671. https://doi.org/10.1016/j.jbusres.2007.02.014

Kam Sing Wong, S., \& Tong, C. (2012). The influence of market orientation on new product success. European Journal of Innovation Management, $15(1), \quad 99-121$. https://doi.org/10.1108/14601061211192852

Lee, S. S., \& Osteryoung, J. S. (2002). Start-Up Business Evaluation Model Using the Analytic Hierarchy Process. The International Journal of Entrepreneurship and Innovation, 3(3), 211-219. https://doi.org/10.5367/000000002101299213

LeRouge, C., Ma, J., Sneha, S., \& Tolle, K. (2013). User profiles and personas in the design and development of consumer health technologies. International Journal of Medical Informatics, 82(11), e251-e268. https://doi.org/10.1016/j.ijmedinf.2011.03.006

Livne, G., Simpson, A., \& Talmor, E. (2011). Do Customer Acquisition Cost, Retention and Usage Matter to Firm Performance and Valuation? Journal of Business Finance \& Accounting, 38(3-4), 334-363. https://doi.org/10.1111/j.1468-5957.2010.02229.x 
Milat, A. J., King, L., Bauman, A. E., \& Redman, S. (2013). The concept of scalability: increasing the scale and potential adoption of health promotion interventions into policy and practice. Health Promotion International, 28(3), 285-298. https://doi.org/10.1093/heapro/dar097

Min, S., Zhang, X., Kim, N., \& Srivastava, R. K. (2016). Customer Acquisition and Retention Spending: An Analytical Model and Empirical Investigation in Wireless Telecommunications Markets. Journal of Marketing Research, 53(5), 728-744. https://doi.org/10.1509/jmr.14.0170

Minshall, T., Seldon, S., \& Probert, D. (2007). Commercializing A Disruptive Technology Based Upon University Ip Through Open Innovation: A Case Study Of Cambridge Display Technology. International Journal of Innovation and Technology Management, 4(3), 225-239. https://doi.org/10.1142/S0219877007001107

Morgan, N. A., Vorhies, D. W., \& Mason, C. H. (2009). Market orientation, marketing capabilities, and firm performance. Strategic Management Journal, 30(8), 909-920. https://doi.org/10.1002/smj.764

Nissen, M. E., Kamel, M. N., \& Sengupta, K. C. (2000). A Framework for Integrating Knowledge Process and System Design. Information Strategy: The Executive's Journal, 16(4), 17-26. https://doi.org/10.1080/07438613.2000.10744621

Øvretveit, J., Garofalo, L., \& Mittman, B. (2017). Scaling up improvements more quickly and effectively. International Journal for Quality in Health Care, 29(8), 1014-1019. https://doi.org/10.1093/intqhe/mzx147

Perren, L. (2003). The role of e-mentoring in entrepreneurial education and support: a meta-review of $\begin{array}{llll}\text { academic literature. } & \text { Education } & + & \text { Training, }\end{array}$ https://doi.org/10.1108/00400910310508900

Raj, R., \& Srivastava, K. B. L. (2016). Mediating role of organizational learning on the relationship between market orientation and innovativeness. The Learning Organization, 23(5), 370-384. https://doi.org/10.1108/TLO-09-2013-0051

Rancic Moogk, D. (2012). Minimum Viable Product and the Importance of Experimentation in Technology Startups. Technology Innovation Management Review, 2(3), 23-26. https://doi.org/10.22215/timreview/535

Richardson, A. (2016). What You Can and Should Be Doing with Your Customer Journeys. Retrieved from Harvard Business Review website: https://hbr.org/2016/03/what-you-can-and-should-be-doing-withyour-customer-journeys

Ries, E. (2011). The Lean Startup: How Today's Entrepreneurs Use Continuous Innovation To Create Radically Successful Businesses. (1st ed.). New York: Crown Publishing Group.

Roberts, E. B., Murray, F., \& Kim, J. D. (2015). Entrepreneurship and Innovation at MIT Continuing Global Growth and Impact. Retrieved from MIT website: http://web.mit.edu/innovate/entrepreneurship2015.pdf

Rochford, L., \& Wotruba, T. R. (1996). The Impact of Sales Management Changes on New Product Success. Journal of the Academy of Marketing Science, 24(3), 263-270. https://doi.org/10.1177/0092070396243007

Salamzadeh, A., \& Kawamorita, H. (2015). Challenges To Promoting Entrepreneurship, Leadership And Competitiveness. Employment, Education and Entrepreneurship (EEE). https://doi.org/10.13140/RG.2.1.3624.8167

Santisteban, J., \& Mauricio, D. (2017). Systematic Literature Review of Critical Success Factors of Information Technology Startups. Retrieved from Semantic Scholar website: https://www.semanticscholar.org/paper/Systematic-Literature-Review-of-Critical-Success-ofSantisteban-Mauricio/a9d7e3873543e9a862cc588e8ed7bcf9d3a540cb

Sekliuckiene, J., Vaitkiene, R., \& Vainauskiene, V. (2018). Organisational Learning in Startup Development and International Growth. Entrepreneurial Business and Economics Review, 6(4), 125-144. https://doi.org/10.15678/EBER.2018.060407

Shukla, A., Swami, S., \& Sharma, N. K. (2010). Website satisfaction: role of user and website characteristics. International Journal of Electronic Marketing and Retailing, 3(2), 114. https://doi.org/10.1504/IJEMR.2010.032869

Simoes, J., Silva, M. J., Trigo, V., \& Moreira, J. (2012). The Dynamics Of Firm Creation Fuelled By Higher Education Institutions Within Innovation Networks. Science and Public Policy, 39(5), 630-640. https://doi.org/10.1093/scipol/scs040

Solomon, M., Bamossy, G. J., Askegaard, S., \& Hogg, M. K. (2006). Consumer Behaviour: A European Perspective (3rd ed.). London: Prentice-Hall Publisher.

Sosna, M., Trevinyo-Rodríguez, R. N., \& Velamuri, S. R. (2010). Business Model Innovation through Trialand-Error Learning. Long Range Planning, 43(2-3), 383-407. https://doi.org/10.1016/j.lrp.2010.02.003 
Spender, J.-C., Corvello, V., Grimaldi, M., \& Rippa, P. (2017). Startups and open innovation: a review of the literature. European Journal of Innovation Management, 20(1), 4-30. https://doi.org/10.1108/EJIM-122015-0131

Stankevich, A. (2017). Explaining the Consumer Decision-Making Process: Critical Literature Review. JOURNAL OF INTERNATIONAL BUSINESS RESEARCH AND MARKETING, 2(6), 7-14. https://doi.org/10.18775/jibrm.1849-8558.2015.26.3001

Trott, P. (2017). Innovation Management and New Product Development (6th ed.). London: Pearson.

Weaver, C. N. (1995). Managing the Four Stages of TQM: How to Achieve World-class Performance. Milwaukee: ASQC Quality Press.

Westley, F., Antadze, N., Riddell, D. J., Robinson, K., \& Geobey, S. (2014). Five Configurations for Scaling Up Social Innovation. The Journal of Applied Behavioral Science, 50(3), 234-260. https://doi.org/10.1177/0021886314532945 